\title{
REACTIVATION AND IMMUNOLOGICAL STUDIES ON A JAPANESE VARIANT OF RED CELL CARBONIC ANHYDRASE I, CA I HIROSHIMA-1
}

\author{
TAKESHI KagEOKA* and RiChaRd E. TASHIAN $\dagger$ \\ Department of Human Genetics, University of Michigan Medical School, Ann Arbor, MI 48109, U.S.A.
}

(Received 26 October 1981)

\begin{abstract}
Under certain conditions, CA I HIR- $1+(86 \mathrm{Asp} \rightarrow \mathrm{Gly})$ was inactivated in $\mathrm{Gnd} \cdot \mathrm{HCl}$ more rapidly than normal $\mathrm{CA} I$.

2. After denaturation in $5.0 \mathrm{M} \mathrm{Gnd} \cdot \mathrm{HCl}, \mathrm{CA}$ I HIR-1 was reactivated more slowly than normal CA I.

3. CA I HIR-1 was precipitated by purified anti-CA I antibodies, under certain conditions, more rapidly than normal $\mathrm{CA} I$.
\end{abstract}

\section{INTRODUCTION}

Studies on the reactivation of denatured enzymes indicate that all of the information necessary to direct the proper refolding of a polypeptide chain into a functional protein is contained within its primary amino-acid sequence (cf. Anfinsen \& Scheraga, 1975). It therefore would be of interest to study the effect on the refolding of a protein whose primary structure has been altered by a mutation which results in an aminoacid substitution, since such information would be useful in determining the importance of an aminoacid residue in the folding efficiency of a particular protein. It would also be of interest to see whether this substitution results in any alteration in antigenic properties. If so, it would suggest that the altered residue is associated with an antigenic site or sites. In this respect, the two human red cell carbonic anhydrase isozymes, CA I and CA II, could serve as excellent candidates for such studies since not only have their primary structures (Andersson et al., 1972; Lin \& Deutsch, 1973, 1974; Henderson et al., 1976) and three-dimensional structures (Liljas et al., 1972; Kannan et al., 1975) been determined, but the amino-acid substitutions for eight inherited variants of human CA I, and one variant of CA II have been reported (cf. Tashian \& Carter, 1976; Tashian et al., 1980). Furthermore, conditions for the nearly complete reactivation of human CA I and CA II denatured in guanidine $\cdot$ hydrochloride $(\mathrm{Gnd} \cdot \mathrm{HCl}$ ) have been described (Carlsson et al., 1973).

In the present study, we have examined the refold. ing and antigenic properties of a mutant human red cell carbonic anhydrase I, CA I Hiroshima-1 (CA I HIR-1), in which the amino-acid substitution (86 Asp $\rightarrow$ Gly) has been determined (Kageoka et al., 1981).

* Present address: Department of Internal Medicine University of Tokyo Medical School, Tokyo, Japan.

† To whom all reprint requests should be addressed.

$\ddagger$ Abbreviations used: CA I HIR-1 = CA I Hiroshima-1;

CA I, CA II and CA III = carbonic anhydrases, I, II, and III; Gnd $\cdot \mathrm{HCl}=$ guanidine $\cdot$ hydrochloride.

\section{MATERIALS AND METHODS}

\section{Enzyme purification}

Normal CA I and CA I HIR-1 were purified from hemolysates of heterozygous individuals by affinity chromatography on sulfonamide-bound, CM-Sephadex columns as previously described (Osborne \& Tashian, 1975). Further purification was achieved by passing the normal and variant enzymes through a DEAE-cellulose column equilibrated with $0.024 \mathrm{M}$ Tris- $\mathrm{HCl}$ buffer, $\mathrm{pH} 8.7$. Protein concentrations were determined spectrophotometrically at $280 \mathrm{~nm}$ assuming an extinction coefficient of $E_{1 \% \mathrm{~m}}^{1 \%}=16.3$ for human CA I (Nyman \& Lindskog, 1964).

\section{Inactivation in $\mathrm{Gnd} \cdot \mathrm{HCl}$}

The normal and variant enzymes $(0.4 \mathrm{mg} / \mathrm{ml})$ were denatured in various concentrations of $\mathrm{Gnd} \cdot \mathrm{HCl}$ (sequential grade. Pierce Chemical Co., Rockford. Illinois) at 25 or $37^{\circ} \mathrm{C}$ in $0.1 \mathrm{M}$ Tris $-\mathrm{SO}_{4}$ buffer, $\mathrm{pH} 7.5$. At various time intervals, aliquots were removed and assayed for esterase activity.

\section{Reactivation after denaturation in $\mathrm{Gnd} \cdot \mathrm{HCl}$}

Reactivation of various concentrations of the normal and variant enzymes which had becn denatured in $5.0 \mathrm{M}$, Gnd $\mathrm{HCl}$ for $24 \mathrm{hr}$ at $25^{\circ} \mathrm{C}$, was initiated by rapid dilution to $0.5 \mathrm{M} \mathrm{Gnd} \cdot \mathrm{HCl}$ in $0.1 \mathrm{M}$ Tris-SO $\mathrm{S}_{4}, \mathrm{pH} 7.5$, buffer with and without dithiothreitol. Aliquots were removed at various times and assayed for esterase activity.

\section{Immunological procedures}

Purified antihuman CA I antibodies were prepared by adsorption of rabbit antihuman CA I antisera to purified human CA I covalently bound to Sepharose 4B (Porath et al., 1967) and eluted with $0.1 \mathrm{M}$ glycine buffer, pII 2.6. The antibody preparation was dialyzed against $0.0025 \mathrm{M}$ phos-

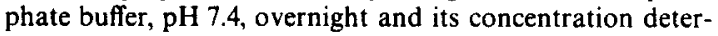
mined spectrophotometrically assuming an extinction coefficient of $E_{1 \% \mathrm{~m}}^{1 \%}=13.8$ at $280 \mathrm{~nm}$ (Porter, 1957).

The precipitation of CA I and CA I HIR-1 with increasing amounts of antibody was accomplished in reaction mixtures containing $0.1 \mathrm{mg} / \mathrm{ml}$ enzyme $(20 \mu \mathrm{l})$ and $20 \mu \mathrm{l}$ of various concentrations of the antibody in $100 \mu \mathrm{l}$ of 0.1 Tris- $\mathrm{SO}_{4}$ buffer, $\mathrm{pH} 7.5$ or 8.0 , incubated at $37^{\circ} \mathrm{C}$ for $60 \mathrm{~min}$. The immunorcaction mixtures were then centrifuged at $10,000 \mathrm{rpm}$ for $20 \mathrm{~min}$ to remove the immunoprecipitates. The supernatant solutions and immunoprecipitates were then assayed for esterase activity. 


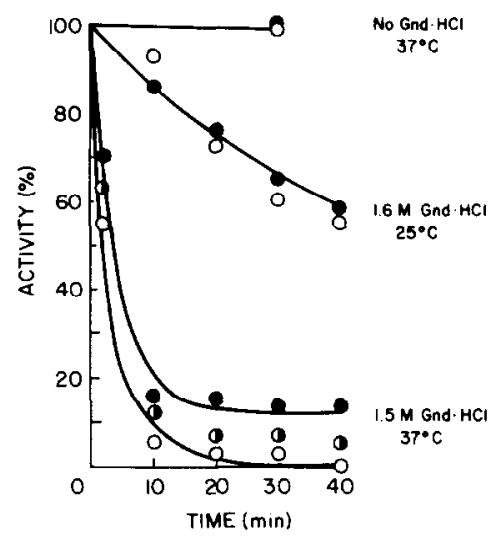

Fig. 1. Time-course for the inactivation of normal CA I and CA I HIR-1 at 25 and $37^{\circ} \mathrm{C}$ in 1.5 and 1.6 M Gnd $\cdot \mathrm{HCl}$. Conditions: enzyme concentrations, $0.4 \mathrm{mg} / \mathrm{ml}$; buffer, $0.1 \mathrm{M}$ Tris-SO ${ }_{4}, \mathrm{pH} \mathrm{7.5}$. CA I (०), CA I HIR-1 (O), CA I + CA I HIR-1 (1:1)(O). No curves were drawn for CA I HIR-1, 1.6 M Gnd $\mathrm{HCl}$ at $25^{\circ} \mathrm{C}$, and $\mathrm{CA}$ $\mathrm{I}+\mathrm{CA}$ I HIR-1, 1.6 $\mathrm{M} \mathrm{Gnd} \cdot \mathrm{HCl}$ at $37^{\circ} \mathrm{C}$.

Time course studies of the precipitation of CA I and CA I HIR-1 by purified human CA I anti-CA I antibodies were carried out in $0.1 \mathrm{M}$ Tris- $-\mathrm{SO}_{4}$ buffer at $\mathrm{pH} 7.0$ and 8.5. Ten microliters of the enzymes $(0.2 \mathrm{mg} / \mathrm{ml})$ and $10 \mu \mathrm{l}$ of the purified $C A I$ antibodies $(3.0 \mathrm{mg} / \mathrm{ml})$ were added to $400 \mu \mathrm{l}$ of $0.1 \mathrm{M}$ Tris-SO $\mathrm{SO}_{4}$ buffer, and incubated at 37 and $25^{\circ} \mathrm{C}$. At various time intervals, aliquots were removed and centrifuged at $10,000 \mathrm{rpm}$ for $2 \mathrm{~min}$. The esterase activity of the supernatant was then measured to determine the extent of inhibition by antibody.

\section{Enzyme assays}

The esterase activities of the carbonic anhydrases were measured spectrophotometrically with $p$-nitrophenyl acetate as substrate by the method of Armstrong et al. (1966).

For the inactivation and reactivation experiments, the assays were carried out in the presence of the same concentration of $\mathrm{Gnd} \cdot \mathrm{HCl}$ as in the reaction mixtures.

The residual esterase activities in the immunoprecipitation experiments were measured by directly assaying the supernatant solutions. The esterase activities of the immunoprecipitates were determined by first washing them 3 times with $0.1 \mathrm{M}$ Tris-SO $\mathrm{S}_{4}$ buffer, $\mathrm{pH} 7.5$ or 8.0 , brought to the initial buffer volume with the same buffer, and then vigorously shaking the solutions containing the immunoprecipitates on a Vortex mixer for 2 min.

All esterase activities are presented as the percent of initial activity.

\section{RESULTS}

\section{Inactivation and reactivation}

As shown in Fig. 1, the relative loss of esterase activity in $1.6 \mathrm{M} \mathrm{Gnd} \cdot \mathrm{HCl}$ proceeded at a similar rate for both the normal and variant enzymes at $25^{\circ} \mathrm{C}$. This was also true for concentrations of $1.5,1.7$ and $2.0 \mathrm{M} \mathrm{Gnd} \cdot \mathrm{HCl}$ (data not shown). At $37^{\circ} \mathrm{C}$, however, CA I HIR-1 (after $10 \mathrm{~min}$ ) exhibited about a $15 \%$ greater loss of activity than normal $\mathrm{CA} I$ in $1.5 \mathrm{M}$ Gnd $\cdot \mathrm{HCl}$. A 1:1 mixture of CA I and CA I HIR-1 showed intermediate values.

After denaturation in $5.0 \mathrm{M} \mathrm{Gnd} \cdot \mathrm{HCl}$, the normal CA I isozymes recovered about 93 and $80 \%$ of their esterase activities in $20 \mathrm{~min}$ at protein concentrations of 0.1 and $0.4 \mathrm{mg} / \mathrm{ml}$, respectively (Fig. 2). However, CA I HIR-1 recovered only about 57 and $67 \%$ of its

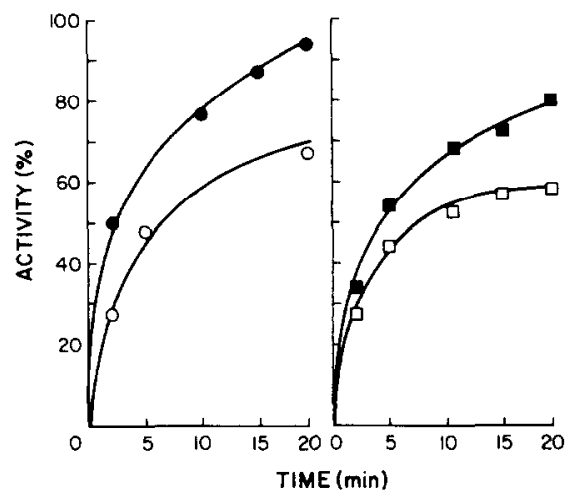

Fig. 2. Time-course for the reactivation of normal CA I and CA I HIR-1 denatured in $5.0 \mathrm{M} \mathrm{Gnd} \cdot \mathrm{HCl}$ for $24 \mathrm{hr}$ at $25^{\circ} \mathrm{C}$ at various protein concentrations: $\mathrm{CA} I, 0.1 \mathrm{mg} / \mathrm{ml}$ (๑); CA I, $0.4 \mathrm{mg} / \mathrm{ml}(\mathbf{\square})$; CA I HIR-1, $0.17 \mathrm{mg} / \mathrm{ml}(\mathrm{O}) ; \mathrm{CA}$ I HIR-1, $0.35 \mathrm{mg} / \mathrm{ml}(\square)$. See Materials and Methods for experimental details.

esterase activity at concentrations of 0.35 and $0.17 \mathrm{mg} / \mathrm{ml}$, respectively. The presence of $1 \mathrm{mM}$ dithiothreitol in the reactivation buffer did not appear to alter the reactivation patterns of the normal and variant enzymes (data not shown).

\section{Immunoprecipitation analysis}

As seen in Fig. 3, the esterase activities of both CA I and CA I HIR-1 in the supernatants of the immunoreaction mixtures decreased with increasing amounts of anti-CA I antibody, with no differences observed between the normal and variant enzymes at $\mathrm{pH} 7.5$ and $\mathrm{pH}$ 8.0. Also, no obvious differences were seen in the esterase activities of the immunoprecipitates produced by the immunological reactions.

In the time-course experiments (Fig. 4), no differences were seen between the normal and variant cnzymes in the esterase activities of the supernatants at $\mathrm{pH} 7.0$ over a 40 -min period. However, at $\mathrm{pH} 8.5$, no further esterase activity in the supernatant was detected for CA I IIIR-1 after $40 \mathrm{~min}$, whereas normal $\mathrm{CA}$ I had about $10 \%$ of its relative activity remaining at the end of this same time period.

\section{DISCUSSION}

During the denaturation and reactivation experiments, it was shown that the CA I variant, CA I

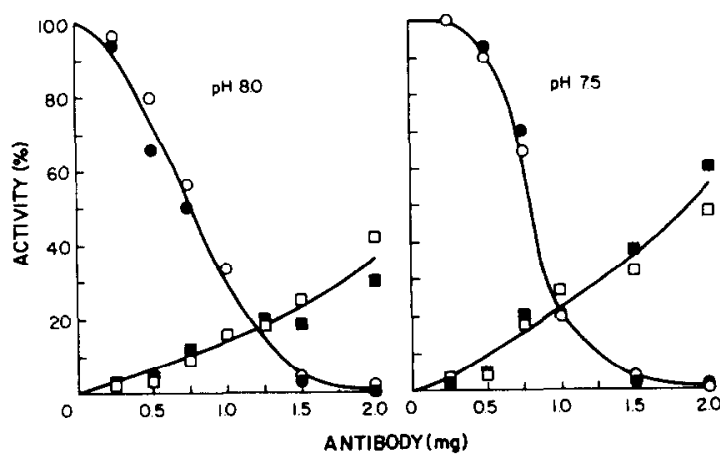

Fig. 3. Precipitation of CA I and CA I HIR-1 by purified anti-CA I antibodies at $\mathrm{pH} 7.5$ and 8.0. Esterase activity of supernatant solutions: CA I (O); CA I HIR-1 (O); esterase activity of immunoprecipitates: CA I (ם); CA I HIR-1 (口).

See Materials and Methods for procedural details. 


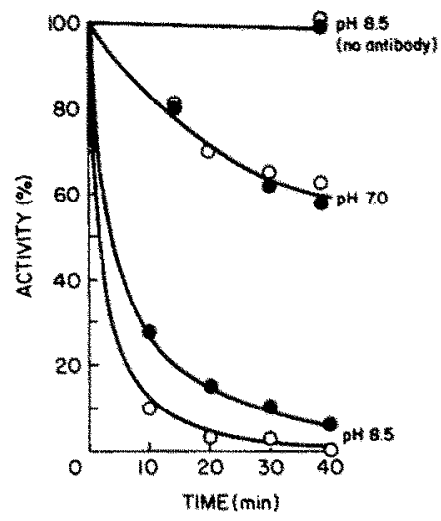

Fig. 4. Time-course for precipitation of $\mathrm{CA} \mathrm{I}$ and $\mathrm{CA} I$ HIR -1 by purified antiwCA I antibodies. Esterase activity of supernatant solutions: CA I, (o); CA I HIR-1 (O). See Materials and Methods for procedural details.

HIR-1, unfolded more rapidly than normal CA under certain conditions (i.e. $37^{\circ} \mathrm{C}, \mathrm{pH} 7.5,1.5 \mathrm{M}$ Gnd $\cdot \mathrm{HCl}$ ), and showed a lower level of reactivation under all of the experimental conditions. It thus appears from these preliminary findings that the substitution of Gly for Asp at position 86 in the variant CA I has the effect of reducing the efficiency of the refolding process. Since residue 86 is on the outside of the human CA 1 molecule, and does not appear to be part of any secondary structure (cf. Notstrand et al. 1975), no obvious mechanism is forthcoming to explain the altered folding pattern. It has previously been reported that $\mathrm{CA}$ I HIR-1 is less thermostable than normal CA I (Kageoka et al., 1981).

Since CA I HIR-1 appears to be more rapidly precipitated than the normal enzyme, by the anti-CA I antibodies, it is possible that the Asp to Gly substitu* tion has somehow increased the binding efficiency of an antigenic site or sites. Two possibilities could account for such a change. Either residue 86 may itself be part of an antigenic reactive region, or the substitution might bring about a conformational change which could alter an antigenic site or sites at another part of the molecule. In this respect, Shapira \& Ben-Yoseph (1976) demonstrated that about one half of the antigenic sites of human CA I did not bind anti CA I antibodies in the presence of the substrate, $\mathrm{HCO}_{3}^{-}$, whereas full binding was observed with the substrates, $\mathrm{CO}_{2}$ or $p$-nitrophenyl acetate. This finding suggests that a conformational change in the active site can produce changes in antigenic determinants that may be far removed from the active site. It would obviously be important to our understanding of these results if the antigenic determinants of human $\mathrm{CA}$ could be localized by methods similar to those used to determine the antigenic reactive regions of myoglow bin (cf. Atassi, 1977).

The meaning of these findings concerning the effect of alterations in the primary structure of a protein on its reactivation characteristics and antigenic determin. ants should become clearer when more structural variants of red cell CA I are similarly examined. In this regard, it would be of particular interest to study the heat stable variant, CA I Michigan-2 $(100$ Thr $\rightarrow$ Lys) (Osborne \& Tashian, 1974), and vari ants which are present at lower levels than the normal enzyme such as the CA I variant, $C A$ la, of the pigtail macaque, Macaca nemestrina, (i.e. $25 \%$ of normal levels) (DeSimone et al., 1973).

If the folding efficiency of CA I HIR 1 is also altered in nivo, it is noteworthy that its synthesis in red cells is not decreased as it has been shown that both normal and variant enzymes are present in ap. proximately equal amounts in hemolysates of individuals that are heterozygous for the variant enzyme (Kageoka et al. 1981). As previously noted, it is of interest that the residue at position 86 is Asp in all mammalian CA I isozymes sequenced to date (i.e. human, chimpanzee, orangutan, rhesus macaque and rabbit); however, in turtle CA I, the CA II isozymes of human, rhesus, sheep, ox and rabbit and the CA III isozymes of human and gorilla, the residue at this position is Gly (Kageoka et al. 1981, and references therein). It thus appears that Gly is the ancestral residue at position 86 , and that the Asp $\rightarrow$ Gly substitution represents a back mutation.

\section{SUMMARY}

Inactivation and reactivation studies and immunoprecipitation experiments were carried out on an inherited variant of red cell CA I, CA I HIR-1 $(86 \mathrm{Asp} \rightarrow \mathrm{Gly})$, previously described from the Japanese population. Under certain conditions, CA I HIR-I was: (1) inactivated in $\mathrm{Gnd} \cdot \mathrm{HCl}$ more rapidly than normal $\mathrm{CA} I ;(2)$ reactivated more slowly than normal $\mathrm{CA} \mathrm{I}$ after denaturation in $5.0 \mathrm{M}$ Gnd $\mathrm{HCl}$; and (3) precipitated more rapidly than normal CA I by purified anti-CA I antibodies.

The results suggest that the substitution of Gly for Asp at position 86 in human CA I (1) interferes with the efficiency of the refolding process and (2) that Gly at position 86 in CA 1 HIR-1 may have the effect of increasing the binding capacity of an antigenic reactive region or regions.

Acknowledgements-We thank Dr James V. Neel for his encouragement and support during this study. Patrick $J$. Venta for his help in preparing the antibodies, and Dr David Hewett-Emmett for his helpful advice during the preparation of the manuscript. The work was supported by USPHS Grant GM 24681 (to R.E.T.) and U.S. Department of Energy contract 2828 (to J. V. Neel).

\section{REFERENCES}

ANDERSSON B., NYMAN P. O. \& Strm L. (1972) Amimo acid sequence of human erythrocyte carbonic anhydrase $B$. Biochem, biophys. Res. Commun. 48, 670-677.

ANFinsen C. B. \& SChfRaGa H. A. (1975) Experimental and theoretical aspects of protein folding. In Adumces in Protein Chemistry Vol. 29 (Edited by EDSALI J. T. \& Richards F. M.). pp. 205-300. Academic Press. New York.

Armstrong I. MCD. Myers D. V. Verpoorte I. A. \& Eosall J. T. (1966) Purification and properties of human erythrocyte carbonic anhydrases. J hol Chem. 241, $5137-5149$.

ATAssI M. Z. (1977) The complete antigenic structure of myoglobin: Approaches and conclusions for antigenic structures of proteins. In Immunochemistry of Proteins, Vol. 2 (Edited by ATassi M. Z), pp. 77-176. Plenum Press. New York.

Carlsson V. Henderson L. E. \& Lindskog S. (1973) De- 
naturation and reactivation of human carbonic anhydrases in guanidine hydrochloride and urea. Biochim. biophys. Acta 310, 376-387.

DeSimone J., Magid E., Linde M. \& Tashian R. E. (1973) Genetic variation in the carbonic anhydrase isozymes of macaque monkeys. III. Biosynthesis of carbonic anhyd. rases in bone marrow erythroid cells and peripheral blood reticulocytes of Macaca nemestrina. Archs Biochem Biophys. 158, 365-376.

Henderson L. E., Henricksson D. \& Nyman P. O. (1976) Primary structure of human carbonic anhydrase C. $J$. biol. Chem. 251, 5457-5463.

Kageoka T., HewetT-Emmett D., Stroup S. K., Yu Y..S. L. \& Tashian R. E. (1981) Amino acid substitution and chemical characterization of a Japanese variant of carbonic anhydrase I: CA I Hiroshima-1 (86 Asp $\rightarrow$ Gly). Biochem. Genet. 19, 535 -549.

Kannan K. K., Notstrand B., Fridborg K., Lövgren S., Ohlsson A. \& Petef M. (1975) Crystal structure of human erythrocyte carbonic anhydrase $B$. Three-dimensional structure at a nominal $2.2 \mathrm{~A}$ resolution. Proc. natn. Acad. Sci. U.S.A. 72, 51-55.

liljas A., Kannan K. K. Bergstén P.-C, WaAra 1 , Fridborg K., Strandberg B., Carlbom V., Järup Lu, Lövgren S. \& Petef M. (1972) Crystal structure of human carbonic anhydrase C. Nature, (Lond.) new Biol. 235, 131-137.

LiN K.-T. D. \& Deutsch H. F. (1978) Human carbonic anhydrases. XI. The complete primary structure of carbonic anhydrase B. J. biol. Chem. 248, 1885-1893.

LiN K.-T. D. \& Deutsch H. F. (1974) Human carbonic anhydrases. XII. The complete structure of the $\mathrm{C}$ isozyme. J. biol. Chem. 249, 2329-2337.
Notstrand B., VaARa I. \& KanNan K. K. (1975) Structural relationship of human erythrocyte carbonic anhydrase isozymes $\mathrm{B}$ and $\mathrm{C}$. In Isozymes, Vol 1 (Edited by Markert C. L.), pp. 575-599. Academic Press, New York.

Osborne W. R. A. \& TAShian R. E. (1974) Thermal inactivation studies of normal and variant human erythrocyte carbonic anhydrases using a sulphonamide binding assay. Biochem. J. 141, 219-225.

Oszorne W. R. A. \& Tashian R. E. (1975) An improved method for the purification of carbonic anhydrase isozymes by affinity chromatography. Analyt. Biochem. 64, $297-303$

Porath J., Axen R. \& ERnback S. (1967) Chemical coupling of proteins to agarose. Nature 215, 1491-1492.

PORTER R. R. (1957) The isolation and properties of a fragment of bovine-serum albumin which retains the ability to combine with rabbit antiserum. Biochem. $J .66$, 677-686.

Nyman P. O. \& Lindskog S. (1964) Amino acid composition of various forms of bovine and human erythrocyte carbonic anhydrase. Biochim biophys. Acta 85, 141-151.

SHAPIRA E. \& BEN-YOSEPH Y. (1976) Immunological evidence for substrate-induced conformation alterations in human carbonic anhydrase B. J. biol. Chem. 251, 4867-4871.

Tashian R. E, \& Carter N. D. (1976) Biochemical gentics of carbonic anhydrase. In Advances in Human Genetics, Vol. 7 (Edited by Harris H. \& HirschHoRN K.), pp. 1-56. Plenum Press, New York.

Tashian R. E. Kendall A. G. \& CARTER N. D. (1980) Inherited variants of human red cell carbonic anhydrases. Hemoglobin 4, 635-651. 